\title{
Competition of copper and zinc for strong ligands in a eutrophic lake
}

\section{HanBin Xue, David Kistler, and Laura Sigg}

Limnological Research Center, Swiss Federal Institute of Environmental Science and Technology (EAWAG), CH6047 Kastanienbaum, Switzerland

\begin{abstract}
Free aquo copper ion and zinc ion concentrations were determined in water samples from eutrophic Lake Greifen by means of ligand exchange with catechol and cathodic stripping voltametry (for $\mathrm{Cu}$ ) and ligand exchange with EDTA and anodic stripping voltametry (for $\mathrm{Zn}$ ). The ratios of total dissolved $\mathrm{Zn}(10-40 \mathrm{nM}$ ) to dissolved $\mathrm{Cu}(7-20 \mathrm{nM})$ were $[\mathrm{Zn}]:[\mathrm{Cu}]=0.5-3$ in samples taken at different seasons of a year; the ratios of the free aquo ion concentrations $\left[\mathrm{Zn}^{2+}\right]:\left[\mathrm{Cu}^{2+}\right]$ were $\sim 10^{6} . \mathrm{pCu}$ was in the range of $14.5-15.9$ and $\mathrm{pZn}$ 8.6-9.5 at different times and depths. The release of $\mathrm{Zn}$ from electrochemically inert complexes upon addition of $\mathrm{Cu}$ suggested direct competition of $\mathrm{Cu}$ and $\mathrm{Zn}$ for ligands in all lake-water samples examined. The selectivity of the natural ligands for $\mathrm{Cu}$ over $\mathrm{Zn}$ was evaluated as the conditional constant for the reaction $\mathrm{Cu}^{2+}+\mathrm{ZnL}_{1}$ $=\mathrm{Zn}^{2}+\mathrm{CuL}_{1} ; K=(1.4 \pm 0.9) \times 10^{6}$ (average in the euphotic zone; $\left.\mathrm{pH} 8\right)$. These highly selective ligands are probably of biological origin.
\end{abstract}

$\mathrm{Cu}$ and $\mathrm{Zn}$ are essential elements for biological activity, but they may be toxic at elevated concentrations, as has been demonstrated in marine phytoplankton (Brand et al. 1986; Sunda and Huntsman 1992). Phytoplankton may, in turn, affect trace metal chemistry by releasing metal-complexing ligands as well as by metal binding on surfaces and uptake and sedimentation in natural waters (Bruland et al. 1991; Sunda 1994; Xuc and Sigg 1993). The free metal ion concentration-a key parameter for the reactivity, bioavailability, and effects of metals (Sunda 1994; Sunda and Guillard 1976) - is regulated by complex interactions between trace metal ions, ligands, and major ions and particles (Whitfield and Turner 1987; Bruland et al. 1991). To assess the fate and biological effects of trace metals in natural waters, it is thus essential to determine metal speciation and especially to evaluate the free aquo metal ion concentrations.

$\mathrm{Cu}$ and $\mathrm{Zn}$ complexation in seawater have been extensively studied (e.g. Sunda and Huntsman 1991; Coale and Bruland 1990; Donat and Bruland 1990), but few studies on freshwater systems are available. $\mathrm{Cu}$ is strongly complexed by organic ligands in seawater; $\mathrm{Zn}$ is also present mostly in organic complexes in the upper layers of the central Pacific (Bruland 1989; Bruland et al. 1991).

Our recent studies on $\mathrm{Cu}$ and $\mathrm{Zn}$ speciation in freshwater (Xue and Sigg 1993, 1994) showed that in the water column of a eutrophic lake (Lake Greifen), $\mathrm{Cu}$ is strongly complexed by organic ligands, which are probably biologically produced, giving $\log \left[\mathrm{Cu}^{2+}\right]=-16$ to -14 , whereas a substantial part of $\mathrm{Zn}$ is present as free $\mathrm{Zn}$ ions and weak organic complexes. The ratios of the free aquo ion concentrations $\left[\mathrm{Zn}^{2+}\right]:\left[\mathrm{Cu}^{21}\right]$ were estimated to be in the range of $10^{5}-10^{6}$ in this lake; however, the results

\footnotetext{
Acknowledgments

We thank Silke Meyns for chlorophyll measurements, HansRudolf Bürgi for discussions on algae in Lake Greifen, and Werner Stumm for suggestions on the paper.
}

for $\mathrm{Cu}$ and $\mathrm{Zn}$ were not obtained in the same samples. These ratios may reflect the different tendency of $\mathrm{Cu}$ and $\mathrm{Zn}$ for binding to strong organic ligands. These findings raise questions about the selectivity of the ligands involved, their sources, and their possible significance in maintaining low levels of $\left[\mathrm{Cu}^{2+}\right]$ and corresponding $\left[\mathrm{Zn}^{2+}\right]$ in productive lakes.

Here we investigate whether direct competition between $\mathrm{Cu}$ and $\mathrm{Zn}$ for the strong natural ligands can be demonstrated and attempt to quantify the selectivity of these ligands for $\mathrm{Cu}$ in comparison to $\mathrm{Zn}$. This study was carried but in Lake Greifen, a small eutrophic lake, bccause our previous investigations had shown the presence of high concentrations of ligands in the lake and because an extensive database on chemical and biological parameters is available for it. $\left[\mathrm{Cu}^{2+}\right]$ and $\left[\mathrm{Zn}^{2+}\right]$ from the same samples in the water column of the lake in different seasons of a year were determined by ligand cxchange and voltametry. We compared the complexation characteristics of $\mathrm{Cu}$ and $\mathrm{Zn}$. We used titrations of samples with $\mathrm{Cu}$ or with $\mathrm{Zn}$ to evaluate their competition for the natural ligands. We present the resulting exchange constants and discuss the possible sources of the strong organic ligands.

Theoretical background of the determination of $\left[\mathrm{Cu}^{2+}\right]$ and $\left[\mathrm{Zn}^{2+}\right]$ and of calculations of $\mathrm{Cu}-\mathrm{Zn}$ exchange constants

$\left[\mathrm{Cu}^{2+}\right]$ and $\left[\mathrm{Zn}^{2+}\right]-$ The methods used to determine $\left[\mathrm{Cu}^{2+}\right]$ and $\left[\mathrm{Zn}^{2+}\right]$ have been previously optimized for freshwater conditions; ligand-exchange theory and the $\left[\mathrm{Cu}^{2+}\right]$ and $\left[\mathrm{Zn}^{2+}\right]$ determinations have been described elsewhere (Van den Berg 1984; Xue and Sigg 1993, 1994).

No labile $\mathrm{Cu}$ can be detected by DPASV (differential pulse anodic stripping voltametry) in these samples; therefore, an indirect method must bc uscd for $\mathrm{Cu}$ speciation. Briefly, $\left[\mathrm{Cu}^{2+}\right]$ and complexation parameters for natural organic ligands are determined by competition 
between the natural organic ligands and the ligand catechol, which is added in excess. The concentration of $\mathrm{Cu}$ catechol complexes at equilibrium depends on the concentrations and stability constants of the natural ligands in the sample and can be measured by differential pulse cathodic stripping voltametry (DPCSV), c.g. the reduction current of copper-catechol complexes adsorbed onto the surface of a hanging mercury drop electrode (HMDE) is measured. $\left[\mathrm{Cu}^{2+}\right]$ is calculated from cquilibrium relationships with the catechol complexes.

Titrations of lake waters with $\mathrm{Cu}$ and determination of frec cupric ion concentrations as a function of total $\mathrm{Cu}$ are interpreted with a two-ligand model. The direct results of these titration experiments are values of $\mathrm{pCu}$ and $\Sigma K_{i}\left[\mathrm{~L}_{i}\right]$, the product of the stability constants and of the ligand concentrations. The approximation of this complex system by fitting to a simple two-ligand model represents a simplification. The FITEQL program (Westall 1982 ) was used to estimate conditional stability constants $\left(K_{1}\right.$ and $\left.K_{2}\right)$ and ligand concentrations $\left(\mathrm{L}_{1}\right.$ and $\left.\mathrm{L}_{2}\right)$.

$\left[\mathrm{Zn}^{2+}\right]$ was determined from measurements of labile $\mathrm{Zn}$ by DPASV, ligand exchange with EDTA (ethylenediaminetetraacetate), and equilibrium calculations (Xue and Sigg 1994). Total dissolved $\mathrm{Zn}$ in lake waters include labile and inert species with respect to voltametric methods. Inert $\mathrm{Zn}$ species are nonreducible complexes at the electrode surface or are not dissociated in the boundary layer at the chosen potential; these inert species include strong organic complexes and $\mathrm{Zn}$ adsorbed on colloidal particles. In interpreting the data, we considered the inert species to be strong organic complexes. The labile species include free aquo ions, inorganic, and weak organic complexes. The peak current obtained by DPASV $\left(i_{p}\right)$ is regarded as a measure of the sum of all labile $\mathrm{Zn}$ species. The ZnEDTA complex is inert in terms of DPASV.

When EDTA is added to lake water under certain conditions, it competes with inorganic and labile organic ligands for $\mathrm{Zn}$. The concentration of ZnEDTA complex is determined-at equilibrium with a given EDTA concentration - from the difference in labile $\mathrm{Zn}$ before and after adding EDTA. The concentration of free $\mathrm{Zn}$ ion in the original water can then be calculated from the equilibrium with EDTA. The results of the $\mathrm{Zn}$ speciation experiments are concentrations of inert complexes $\left(\mathrm{ZnL}_{1}\right)$, of weak organic (labile) complexes $\left(\mathrm{ZnL}_{2}\right)$, and of $\mathrm{Zn}^{2+}$. Stability constants of the $\mathrm{ZnL}_{1}$ complexes are not available from these experiments because only the exchange reaction of EDTA with the labile complexes is evaluated quantitatively. The complexing coefficients for $\mathrm{L}_{2}$ (products $\left.K_{2 \mathrm{Zn}}\left[\mathrm{L}_{2}\right]\right)$ are determined by titration with EDTA and measurement of labile $\mathrm{Zn}$.

Conditional constants are used throughout this work for the calculations; the results are therefore expressed as concentrations of $\left[\mathrm{Cu}^{2+}\right]$ and $\left[\mathrm{Zn}^{2+}\right]$ under the conditions given.

Competition of $\mathrm{Zn}$ and $\mathrm{Cu}$ for strong organic ligandsIt is realistic to assume that competition between $\mathrm{Cu}$ and $\mathrm{Zn}$ for strong organic ligands can occur in lake water. To quantify the competition of $\mathrm{Cu}$ and $\mathrm{Zn}$, we measure changes in labile $\mathrm{Zn}$ as a function of the total $\mathrm{Cu}$ con- centration. Therefore, only the competition for ligands forming electrochemically inert complexes with $\mathrm{Zn}$ can be measured directly. We assume 1:1 complexation with the strong ligands for both metals at ambient level. The following mass balances can be written for dissolved $\mathrm{Cu}$ $\left([\mathrm{Cu}]_{\mathrm{T}}\right)$ and $\mathrm{Zn}\left([\mathrm{Zn}]_{\mathrm{T}}\right.$ ), with a strong ligand, $\mathrm{L}_{1}$ (for which competition between $\mathrm{Cu}$ and $\mathrm{Zn}$ is examined), and a weak a ligand, $\mathrm{L}_{2}$,

$$
\begin{aligned}
& {[\mathrm{Cu}]_{\mathrm{T}}=\left[\mathrm{CuL}_{1}\right]+\left[\mathrm{CuL}_{2}\right]+\Sigma\left[\mathrm{Cu}_{\text {inorg }}\right]+\left[\mathrm{Cu}^{2+}\right]} \\
& {[\mathrm{Zn}]_{\mathrm{T}}=\left[\mathrm{ZnL}_{1}\right]+\left[\mathrm{ZnL}_{2}\right]+\Sigma\left[\mathrm{Zn}_{\text {inorg }}\right]+\left[\mathrm{Zn}^{2+}\right] .}
\end{aligned}
$$

$\left[\mathrm{Cu}_{\text {inorg }}\right]$ and $\left[\mathrm{Zn}_{\text {inorg }}\right]$ are the inorganic complexes of $\mathrm{Cu}$ and $\mathrm{Zn}$.

The competition of $\mathrm{Cu}$ and $\mathrm{Zn}$ for $\mathrm{L}_{2}$ is not examined in detail; weak ligands are probably present in excess of the metals in lake water, so competitive effects are not as important for $\mathrm{L}_{2}$ at the ambient levels. $\left[\mathrm{ZnL}_{1}\right]$ is electrochemically inert, and labile $\mathrm{Zn}$ is

$$
[\mathrm{Zn}]_{\text {lab }}=\left[\mathrm{ZnL}_{2}\right]+\Sigma\left[\mathrm{Zn}_{\text {inorg }}\right]+\cdot\left[\mathrm{Zn}^{2+}\right] \text {. }
$$

The mass balance of the ligand $L_{1}$ is

$$
\left[\mathrm{L}_{1}\right]_{\mathrm{T}}=\left[\mathrm{CuL}_{1}\right]+\left[\mathrm{ZnL}_{1}\right]+\left[\mathrm{L}_{1}\right] \text {. }
$$

The stability constants with $\mathrm{L}_{1}$ (conditional for a given $\mathrm{pH})$ are

$$
\mathrm{Cu}^{2+}+\mathrm{L}_{1}=\mathrm{CuL}_{1} \quad K_{1 \mathrm{Cu}}=\frac{\left[\mathrm{CuL}_{1}\right]}{\left[\mathrm{L}_{1}\right]\left[\mathrm{Cu}^{2+}\right]}
$$

and

$$
\mathrm{Zn}^{2+}+\mathrm{L}_{1}=\mathrm{ZnL}_{1} \quad K_{1 \mathrm{Zn}}=\frac{\left[\mathrm{ZnL}_{1}\right]}{\left[\mathrm{L}_{1}\right]\left[\mathrm{Zn}^{2+}\right]} .
$$

The exchange constant is defined for the reaction

$$
\mathrm{Cu}^{2+}+\mathrm{ZnL}_{1}=\mathrm{Zn}^{2+}+\mathrm{CuL}_{1}
$$

with the constant

$$
K_{\mathrm{ex}}=\frac{\left[\mathrm{CuL}_{1}\right]\left[\mathrm{Zn}^{2+}\right]}{\left[\mathrm{ZnL}_{1}\right]\left[\mathrm{Cu}^{2+}\right]}=\frac{K_{1 \mathrm{Cu}}}{K_{1 \mathrm{Zn}}}
$$

During titration of lake water with $\mathrm{Cu}, \mathrm{Cu}$ replaces $\mathrm{Zn}$ in the complexes with $\mathrm{L}_{1}$, and the labile $\mathrm{Zn}$ concentration increases. The following mass balances can thus be written (where $\left[\mathrm{ZnL}_{1}\right]_{0}$ and $\left[\mathrm{CuL}_{1}\right]_{0}$ are the concentrations of $\mathrm{Zn}$ and $\mathrm{Cu}$ bound to $\mathrm{L}_{1}$ in the original water sample, and $\Delta[\mathrm{Zn}]_{\mathrm{lab}}$ is the increase of labile $\mathrm{Zn}$ at a given $\mathrm{Cu}$ addition):

$$
\begin{aligned}
& {\left[\mathrm{ZnL}_{1}\right]=[\mathrm{Zn}]_{\mathrm{T}}-[\mathrm{Zn}]_{\text {lab }}=\left[\mathrm{ZnL}_{1}\right]_{0}-\Delta[\mathrm{Zn}]_{\text {lab }} ;} \\
& {\left[\mathrm{CuL}_{1}\right]=\left[\mathrm{CuL}_{1}\right]_{0}+\Delta[\mathrm{Zn}]_{\text {lab }} .}
\end{aligned}
$$

These equations are valid if the increase in $\left[\mathrm{CuL}_{1}\right]$ is matched by the decrease in $\left[\mathrm{ZnL}_{1}\right]$. The exchange constant can be written as

$$
K_{\mathrm{ex}}=\frac{\left(\left[\mathrm{CuL}_{1}\right]_{0}+\Delta[\mathrm{Zn}]_{\mathrm{lab}}\right)\left[\mathrm{Zn}^{2+}\right]}{\left([\mathrm{Zn}]_{\mathrm{T}}-[\mathrm{Zn}]_{\mathrm{lab}}\right)\left[\mathrm{Cu}^{2+}\right]} .
$$

After reorganization, we obtain the expression

$$
\frac{\left([\mathrm{Zn}]_{\mathrm{T}}-[\mathrm{Zn}]_{\mathrm{lab}}\right)\left[\mathrm{Cu}^{2+}\right]}{\left[\mathrm{Zn}^{2+}\right]}=\frac{\left[\mathrm{CuL}_{1}\right]_{0}}{K_{\mathrm{ex}}}+\frac{\Delta[\mathrm{Zn}]_{\mathrm{lab}}}{K_{\mathrm{ex}}} .
$$


When a water sample is titrated with $\mathrm{Cu},\left[\mathrm{Cu}^{2+}\right]$ can be determined as indicated above at any point of the titration. $[\mathrm{Zn}]_{\text {lab }}$ can also be measured at each point, and $\left[\mathrm{Zn}^{2+}\right]$ is calculated by means of the complexing coefficient for the weak organic ligands and inorganic ligands. Plotting the left side of Eq. 12 as a function of $\Delta[\mathrm{Zn}]_{\text {lab }}$ should yield a linear relationship. $K_{\mathrm{ex}}$ and $\left[\mathrm{CuL}_{1}\right]_{0}$ can be evaluated from the slope and intercept of this function.

If most dissolved $\mathrm{Cu}$ is complexed with $\mathrm{L}_{1}$ in lake water, the mass balance (Eq. 1) can be simplified to

$$
\left[\mathrm{CuL}_{1}\right] \approx[\mathrm{Cu}]_{\mathrm{T}},
$$

and the exchange constant can be written as

$$
K_{\mathrm{ex}}=\frac{[\mathrm{Cu}]_{\mathrm{T}}\left[\mathrm{Zn}^{2+}\right]}{\left([\mathrm{Zn}]_{\mathrm{T}}-[\mathrm{Zn}]_{\mathrm{lab}}\right)\left[\mathrm{Cu}^{2+}\right]} .
$$

The $\mathrm{Cu}-\mathrm{Zn}$ exchange constant can be obtained from the parameters on the right side of Eq. 13 (determined in an original water sample) and from the first few points of a titration of lake water with $\mathrm{Cu}$, for which the differences in labile $\mathrm{Zn}$ are larger and the values are therefore more precise than values in the later part of the titration curve.

From the exchange constant $K_{\text {ex }}$ and the stability constant $K_{\mathrm{ICu}}$ for the $\mathrm{CuL}_{1}$ complex, the conditional stability constant $K_{1 \mathrm{zn}}$ for $\mathrm{ZnL}_{1}$ (strong organic complexes) is readily obtained from Eq. 8.

It is difficult to distinguish between different ligands in lake-water samples. We therefore assume only one type of strong ligand in order to evaluate the competition between $\mathrm{Cu}$ and $\mathrm{Zn}$. A one- or two-ligand model is in any case a strong simplification of the natural system, in which many different types of ligands are present.

Model calculations that use the parameters extracted from the experiments give insights into variations of the complex species; these calculations were performed with the Mac $\mu \mathrm{QL}$ program (Müller 1993; Westall 1979).

\section{Experimental}

Water samples were collected from the water column of Lake Greifen, Switzerland, at its deepest point in different scasons of 1993 (four samplings over $1 \mathrm{yr}$ ). The lake is highly eutrophic and has a surfacc area of $8.5 \mathrm{~km}^{2}$ and a volume of $150 \times 10^{6} \mathrm{~m}^{3}$. Its average depth is 17.7 $\mathrm{m}(\max , 32.2 \mathrm{~m})$. The tributaries of the lake are highly loaded with nutrients and pollutants from sewage and agriculture. The geochemical background of the lake is dominated by calcite. The major ion composition of Lake Griefen is characterized by $\mathrm{Ca} \approx 1.2-1.6 \mathrm{mM}, \mathrm{Mg} \approx 0.6$ $\mathrm{mM}$, and alkalinity $\approx 3.6-4.1 \mathrm{mM}$; $\mathrm{pH}$ is $7.5-8.5$, with variations in time and depth. Dissolved organic C is 3$4 \mathrm{mg}$ liter $^{-1}$ in the water column. The lake is sampled regularly each month for routine parameters such as oxygen, nutrients, and chlorophyll (Limnology Department, EAWAG). Previous investigations of the depth profiles of dissolved $\mathrm{Zn}$ and $\mathrm{Cu}$ have been carried out over 1-2 full seasonal cycles (Sigg et al. 1995).

We used GoFlo bottles (General Oceanics, 5 liters) to collect samples from different depths (10-12 samples at different depths for nutrients and total concentrations and 2-4 samples for speciation experiments). The samples were transferred from the GoFlo to polyethylene bottles under $\mathrm{N}_{2}$ pressure. All the bottles and GoFlo sampling bottles, as well as the filtration devices and filters $(0.45$ $\mu \mathrm{m})$, were carefully cleaned with $\mathrm{HNO}_{3}$ and double-distilled water. Samples were filtered and further treated just after transport to the laboratory. Filtration was performed under clean-bench conditions.

Total dissolved $\mathrm{Cu}$ was directly measured in acidified samples by graphite furnace atomic absorption spectrometry. Total dissolved $\mathrm{Zn}$ was determined in acidified samples by flame atomic absorption spectrometry after preconcentration, using the extraction of 8-hydroxyquinoline complexes on SepPak $\mathrm{C}_{18}$ resins (Sigg et al. 1995).

$\mathrm{Ca}$ and $\mathrm{Mg}$ were measured by inductively coupled plasma emission spectrometry. Total inorganic $\mathrm{C}$ and carbonate concentrations (used to calculate $\mathrm{Zn}$ and $\mathrm{Cu}$ speciation) were calculated from alkalinity (measured by Gran titration) and $\mathrm{pH}$ measurements. Phosphate and silicate were measured by standard spectrophotometric methods on an autoanalyzer. Chlorophyll $a$ was measured by HPLC (Meyns et al. 1994).

DPCSV and DPASV measurements for speciation of $\mathrm{Cu}$ and $\mathrm{Zn}$ were carried out within a week of collection. The filtered samples were stored in the dark at $4^{\circ} \mathrm{C}$ until use. No detectable effects of storage and wall adsorption were observed (Xue and Sigg 1993, 1994).

DPCSV measurement of Cu-catechol complexes and titration curve with $\mathrm{Cu}$-Details of free cupric ion concentration determination have been described elsewhere (Van den Berg 1984; Xue and Sigg 1993). Briefly, DPCSV was performed with a hanging mercury drop electrode, an $\mathrm{Ag} / \mathrm{AgCl}$ referencc, and a graphite counter electrode held in a Metrohm VA 663 stand combined with a 646 VA processor. Catechol was added to the samples after 5 min of purging with suprapure $\mathrm{N}_{2}$. Equilibration was allowed for 5 min under $\mathrm{N}_{2}$. A new $\mathrm{Hg}$ drop was made and the stirrer switched on simultaneously. The Cu-catechol complexes were collected on the electrode at $0 \mathrm{~V}$ for $2 \mathrm{~min}$. After the collection period, the stirrer was turned off, and $15 \mathrm{~s}$ later the voltage scan was initiated in the negative direction.

To obtain a $\mathrm{Cu}$ titration curve of a lake-water sample, we spiked a series of subsamples with different concentrations of $\mathrm{Cu}$. Subsamples $(25 \mathrm{ml})$ of lake water were pipetted into a series of $50-\mathrm{ml}$ high-density polyethylene beakers; $150 \mu \mathrm{l}$ of HEPES buffer (a solution containing 1 M $N$-2-hydroxyethylpiperazine- $N^{\prime}$-2-ethanesulfonic acid and $0.5 \mathrm{M} \mathrm{NaOH}$ ) was added to each beaker to give a final concentration of $6 \times 10^{-3} \mathrm{M}$ HEPES and a final $\mathrm{pH}$ of $8.0 \pm 0.1$, which is close to the natural $\mathrm{pH}$ of the lake water. $\mathrm{Cu}$ was added to all beakers but one. The series was allowed to equilibrate at $20 \pm 2^{\circ} \mathrm{C}$ overnight. DPCSV analyses were performed in the same polyethylene beakers to minimize adsorption effects. The DPCSV sensitivity had to be calibrated for each individual lake-water 
sample because of the effects of different organic compounds on the sensitivity, which varied between 0.25 and $0.40 \mathrm{~A} \mathrm{~mol}^{-1}$ liter $^{-1}$. Sensitivity was determined from the portion of the titration curve at high concentrations of $\mathrm{Cu}^{2+}$, where stronger organic ligands are saturated and the increase of catechol complexes is proportional to added $\mathrm{Cu} .\left[\mathrm{Cu}^{2+}\right]$ was indirectly determined by equilibrium calculations from the measured concentration of $\mathrm{Cu}$-catechol complexes (Xue and Sigg 1993) using stability constants from Martell and Smith (1974-1989).

DPASV measurement of labile $\mathrm{Zn}$ and titrations with $\mathrm{Zn}$ or EDTA-DPASV measurements of labilc $\mathrm{Zn}$ were performed with the same apparatus that was used for DPCSV determination of Cu-catechol complexes. After 10 min of purging with suprapure $\mathrm{N}_{2}$, we made a new $\mathrm{Hg}$ drop and simultaneously switched on the stirrer. Labile $\mathrm{Zn}$ was deposited at $-1.2 \mathrm{~V}$ for a period of $2 \mathrm{~min}$ under stirring followed by a 15 -s rest; scanning then began in the positive direction (Xuc and Sigg 1994).

To calibrate DPASV sensitivity of labile $\mathrm{Zn}$, we titrated lake water with standard $\mathrm{Zn}$ ion solution. Aliquots $(25$ $\mathrm{ml}$ ) of lake water were pipetted into a series of beakers with $6 \times 10^{-3} \mathrm{M}$ HEPES buffer at $\mathrm{pH} 8.0 \pm 0.1$. $\mathrm{Zn}$ was added to all beakers but one for each series. All beakers were kept in the dark overnight until DPASV measurement. The DPASV sensitivity for $\mathrm{Zn}$ in lake water is in the range 0.045-0.052 $\mathrm{A} \mathrm{mol}^{-1}$ liter $^{-1} \mathrm{~min}^{-1}$.

Free $\mathrm{Zn}$ ion concentration and $\mathrm{Zn}$ speciation were calculated from the labile $\mathrm{Zn}$ measurement at different concentrations of EDTA (with stability constants from Martell and Smith 1974-1989); [ZnEDTA] is calculated as the difference between initially labile $\mathrm{Zn}$ and measured labile $\mathrm{Zn}$ after addition of EDTA. Lake waters were thus titrated with EDTA in the same concentration range used for initially labile $\mathrm{Zn}$. Aliquots $(25 \mathrm{ml})$ of lake water were pipetted into a series of the beakers, $6 \times 10^{-3} \mathrm{M}$ of HEPES buffer was added, and the aliquots were spiked with different concentrations of EDTA $(10-50 \mathrm{nM})$ in 3-5 steps. All the prepared samples were allowed to equilibrate in the dark overnight before DPASV measurement.

Competition of $\mathrm{Cu}$ and $\mathrm{Zn}$ for ligands - The competition of $\mathrm{Cu}$ with $\mathrm{Zn}$ for organic ligands was examined by adding $\mathrm{Cu}$ to samples in the concentration range $2 \times$ $10^{-9}-3 \times 10^{-7} \mathrm{M}$. The samples were cquilibrated overnight $(15-20 \mathrm{~h})$. Labile $\mathrm{Zn}$ by DPASV and $\left[\mathrm{Cu}^{2+}\right]$ by exchange with catechol were measured as described above at each titration point; labile $\mathrm{Zn}$ was measured before addition of catechol. The instrument was set in DPASV mode for labile $\mathrm{Zn}$ after a sample was placed in the polarographic cell. After measurement of labile $\mathrm{Zn}$, the instrument was switched to DPCSV mode. The desired concentration of catechol was added to the sample following $5 \mathrm{~min}$ of purging with $\mathrm{N}_{2}$, and DPCSV measurement of $\mathrm{Cu}$ catechol was then performed.

In some experiments, lake-water samples were titrated with EDTA in the presence of added $\mathrm{Cu}$. Titration series were equilibrated overnight. Labile $\mathrm{Zn}$ was then measured
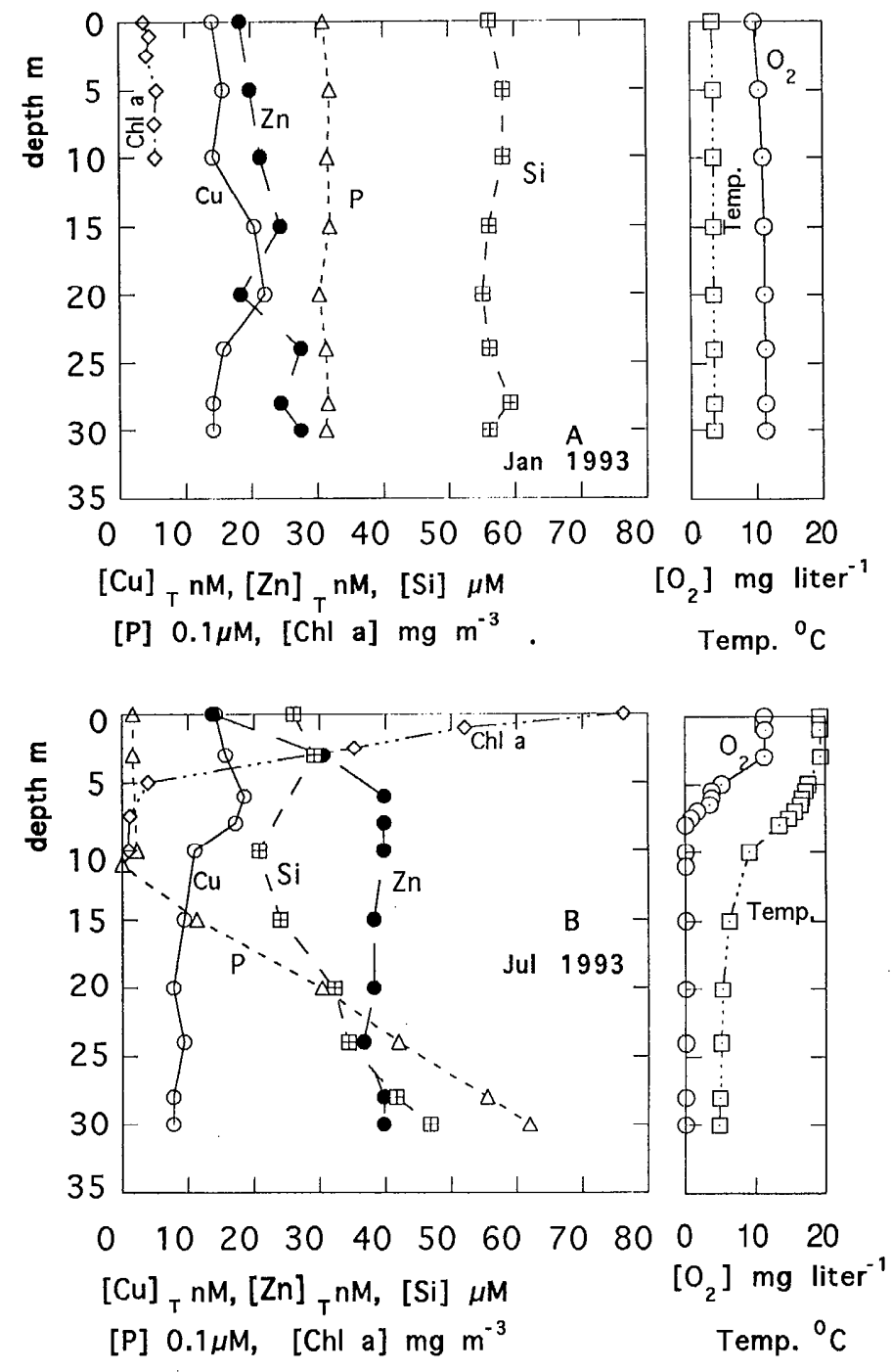

Fig. 1. Vertical profiles of dissolved $\mathrm{Cu}, \mathrm{Zn}$, silicate, orthophosphate, and chlorophyll $a$ concentrations, and $\mathrm{O}_{2}$ and temperature in Lake Greifen in January and July 1993. (Chl $a$ data provided by $\mathbf{S}$. Meyns.)

by DPASV and free $\mathrm{Zn}^{2+}$ concentrations were calculated from equilibration with EDTA in order to cvaluate changes in $\mathrm{Zn}$ speciation. Free $\left[\mathrm{Cu}^{2+}\right]$ was measured in another aliquot of the samples with added $\mathrm{Cu}$.

To cvaluate the cffects of added $\mathrm{Zn}$ on $\mathrm{Cu}$ spcciation, we titrated the water samples with $\mathrm{Zn}$ and equilibrated them overnight. At the ambient $\mathrm{Cu}$ concentration, the concentrations of free cupric ions were too low to be precisely distinguished as a function of added $\mathrm{Zn}$. Some titrations of lake water with $\mathrm{Zn}$ were therefore carried out in the presence of added $\mathrm{Cu}$. Labile $\mathrm{Zn}$ was measured by DPASV, and free cupric ion concentrations were determined by DPCSV of Cu-catechol complexes after addition of catechol in excess. Complexation of $\mathrm{Zn}$ by the added catechol could have only a negligible effect; equilibrium computations indicate that free $\mathrm{Zn}$ ion concen- 
Table 1. Cu speciations in the water column of lake Greifen. $C \mathrm{~L}_{1}$ and $C \mathrm{~L}_{2}$ are the total concentrations of organic ligands $\mathrm{L}_{1}$ and $\mathrm{L}_{2} ; \log K_{1 \mathrm{cu}}$ and $\log K_{2 \mathrm{Cu}}$ are the corresponding conditional stability constants of the $\mathrm{Cu}$ complexes, obtained from fitting the titration data to a two-ligand model (conditional for $\mathrm{pH} 8$ ).

\begin{tabular}{|c|c|c|c|c|c|c|c|c|c|}
\hline \multirow[b]{2}{*}{1993} & \multirow{2}{*}{$\begin{array}{l}\text { Depth } \\
\text { (m) }\end{array}$} & \multirow{2}{*}{$\begin{array}{c}{[\mathrm{Cu}]_{\mathrm{T}}{ }^{*}} \\
(\mathrm{nM})\end{array}$} & \multirow{2}{*}{$\begin{array}{c}{\left[\mathrm{Cu}^{2}\right] \dagger} \\
\left(\times 10^{15}\right. \\
\mathrm{M})\end{array}$} & \multirow[b]{2}{*}{$\mathrm{pCu}$} & \multirow{2}{*}{$\begin{array}{l}{[\mathrm{Cu}]_{\mathrm{T}}:} \\
{\left[\mathrm{Cu}^{2+}\right]} \\
\left(\times 10^{7}\right)\end{array}$} & \multirow[b]{2}{*}{$\log K_{1 \mathrm{Cu}} \ddagger$} & \multirow[b]{2}{*}{$\log K_{2 \mathrm{Cu}} \ddagger$} & $C \mathrm{~L}_{1} \ddagger$ & $C \mathrm{~L}_{2} \ddagger$ \\
\hline & & & & & & & & \multicolumn{2}{|c|}{$(\mathrm{nM})$} \\
\hline \multirow[t]{2}{*}{26 Jạn } & 5 & 15.7 & 0.5 & 15.3 & 3.3 & 15.2 & 12.5 & 27 & 353 \\
\hline & 30 & 14.2 & 3.2 & 14.5 & 0.4 & 13.8 & 11.8 & 99 & 463 \\
\hline \multirow[t]{2}{*}{5 Apr } & 5 & 11.0 & 0.4 & 15.4 & 2.6 & 15.3 & 13.2 & 24 & 275 \\
\hline & 30 & 11.0 & 0.4 & 15.4 & 3.0 & 14.9 & 12.7 & 51 & 284 \\
\hline \multirow[t]{4}{*}{$26 \mathrm{Jul}$} & 3 & 15.7 & 0.7 & 15.2 & 2.4 & 15.2 & 13.2 & 28 & 296 \\
\hline & 6 & 18.6 & 1.6 & 14.8 & 1.2 & 15.1 & 13.3 & 19 & 260 \\
\hline & 8 & 17.2 & 0.5 & 15.2 & 3.2 & 15.1 & 12.9 & 35 & 291 \\
\hline & 30 & 7.9 & 0.1 & 15.9 & 7.1 & 15.6 & 13.4 & 28 & 279 \\
\hline \multirow[t]{2}{*}{$13 \mathrm{Oct}$} & 2.5 & 12.6 & 0.6 & 15.2 & 2.0 & 14.6 & 13.0 & 57 & 333 \\
\hline & 11 & 12.6 & 0.5 & 15.3 & 2.3 & 14.5 & 12.5 & 73 & 373 \\
\hline \multicolumn{10}{|c|}{ Year avg in the euphotic zone } \\
\hline & & 13.8 & 0.6 & 15.3 & 2.6 & 15.1 & 13.0 & 34 & 314 \\
\hline
\end{tabular}

* Measured.

+ Calculated from ligand exchange.

* Two-ligand model fit.

trations would decrease by $<20 \%$ in the presence of catechol.

$\mathrm{Cu}-\mathrm{Zn}$ exchange and competition for an organic ligand have been demonstrated in a modcl solution with EDTA. The selectivity of EDTA for $\mathrm{Cu}$ over $\mathrm{Zn}$ gives an exchange constant $\log K_{\mathrm{ex}} \approx 3$. Increase in labile $\mathrm{Zn}$ was observed when a solution containing $0.2 \mu \mathrm{M} \mathrm{Zn}$ and $0.1 \mu \mathrm{M}$ EDTA was titrated with $\mathrm{Cu}$. The experimental points were in agreement with a calculated curve (obtained by an equilibrium model with $\mathrm{Mac} \mu \mathrm{QL}$ ). The good agreement between calculation and measurement indicates that $\mathrm{Cu}$ compctition with $\mathrm{Zn}$ for a strong ligand leads to $\mathrm{Zn}$ release and to a detectable increase in labile $\mathrm{Zn}$.

\section{Results}

Total dissolved $Z n$ and $C u$ in the water column-Lake Greifen turns over during winter (December-January), and the thermocline develops in May-June. The deeper part of the lake becomes anoxic in May-June, and the hypolimnion below $\sim 10-\mathrm{m}$ depth remains anoxic from about Junc to November.

Total concentrations of dissolved $\mathrm{Zn}(<0.45 \mu \mathrm{m})$ in the water column of the lake were $10-40 \mathrm{nM}$; total concentrations of dissolved $\mathrm{Cu}$ were 7-20 nM. Systematic variations of total dissolved $\mathrm{Zn}$ over the seasonal cycle were obscrved in 1993; these variations were similar to those found in a more detailed study done in 1989-1990 (Sigg et al. 1995). A slight depletion of $\mathrm{Zn}$ from the epilimnion was observed during summer stagnation; during lake overturn, homogeneous concentrations of $\mathrm{Zn}$ were measured throughout the water column, as illustrated by the depth profiles in Fig. 1. Zn became depleted from the entire water column during late stagnation (October, data not shown).
Results on total dissolved $\mathrm{Cu}$ showed no depletion from the epilimnion in summer; in contrast, somewhat higher $\mathrm{Cu}$ concentrations were observed in the epilimnion than in the hypolimnion during summer stagnation.

The ratio of total dissolved $\mathrm{Zn}$ to $\mathrm{Cu}$ in the water column was thus $\mathrm{Zn}: \mathrm{Cu} \approx 2-3\left(\mathrm{~mol} \mathrm{~mol}{ }^{-1}\right)$ during lake mixing; this ratio remained rather constant in the hypolimnion, but it decreased to $\mathrm{Zn}: \mathrm{Cu} \approx 0.5-1$ in the epilimnion during summer.

The differences between the depth profiles of $\mathrm{Cu}$ and $\mathrm{Zn}$ can be explained by the relative importance of inputs into the epilimnion and removal by sedimentation. During summer stagnation, the inputs occur into the epilimnion; the removal rates from the epilimnion by sedimentation are higher during summer for $\mathrm{Zn}$ than for $\mathrm{Cu}$ (Sigg et al. 1995). $\mathrm{Zn}$ is depleted in the epilimnion during summer stagnation, whercas $\mathrm{Cu}$ accumulates. The strong complexation of $\mathrm{Cu}$ probably affects the extent of removal by sedimentation; this effect is not as significant, however, as expected from the large difference in speciation between $\mathrm{Cu}$ and $\mathrm{Zn}$. More data for 1993 than are available here would be needed to quantitatively evaluate the removal rates and mass balances of $\mathrm{Cu}$ and $\mathrm{Zn}$.

$\left[\mathrm{Cu}^{2+}\right]$ and $\mathrm{Cu}$ complexation - The $\left[\mathrm{Cu}^{2+}\right]$ concentrations in the lake are very low, with an average $\mathrm{pCu}$ in the euphotic zone $15.3 \pm 0.1$ (Table 1). The complexing parameters in the eutrophic zone and their average over the year are also listed in Table 1 . The ratio of $[\mathrm{Cu}]_{T}$ to $\left[\mathrm{Cu}^{2+}\right]$, a measure of the complexation of $\mathrm{Cu}$-organic ligands, is very high $(2.55 \pm 0.54) \times 10^{7}$, close to the highest values observed in 1990. Most of the total dissolved Cu $(\gg 99 \%)$ must thus be present in the form of organic complexes. The concentrations of the strong ligands, $\mathrm{L}_{1}$, obtained from fits of the titration data, always exceeded dissolved $\mathrm{Cu}$; the weaker ligands, $\mathrm{L}_{2}$, show an even larger excess. 
Some differences in the samples are observed as a function of depth (Table 1). In the samples on 26 January 1993, $\mathrm{Cu}$ is much more strongly complexed in the $5-\mathrm{m}$ sample than in the 30-m sample. This difference is less obvious in the April and July samplings. In the October samples, no $\mathrm{Cu}$ speciation measurement could be obtained in the $30-\mathrm{m}$ sample, probably because of interferences by sulfide. The $\mathrm{Cu}$ speciation in the water column in July exhibited an interesting behavior related to stratification. The thermocline was observed at $\sim 7-8$-m depth; oxygen decreased from $11.3 \mathrm{mg} \mathrm{liter}^{-1}$ at $0-3 \mathrm{~m}$ to 3.8 at $6 \mathrm{~m}$ and $<0.1$ at $8 \mathrm{~m}$. The total dissolved $\mathrm{Cu}$ concentration at $6 \mathrm{~m}$ was only a little more than that at $3 \mathrm{~m}$, although the free cupric ion concentration was 2.5 times higher. $\left[\mathrm{Cu}^{2+}\right]$ decreased sharply from 6 to $8 \mathrm{~m}$, which means over the oxic-anoxic interface. The stability constants for strong ligands obtained in the samples at 3,6, and $8 \mathrm{~m}$ are very similar; the concentration of strong ligands is, however, lower in the 6-m sample than in the 3- and 8-m samples. These differences indicate that in the 6-m layer, mineralization processes, by which part of these ligands is decomposed, are predominant.

Differences between samples become clearer when the $\mathrm{Cu}$ titration curves rather than the overall results given in Table 1 are compared. Some titration data for $\left[\mathrm{Cu}^{2+}\right]$ and their fitted curves with a two-ligand model are plotted in Fig. 2. The data could be fitted well by using the stability constants and ligand concentrations (Table 1) obtained with the FITEQL program (Westall 1982). A sideby-side comparison of the titration curvès, plotted as $\log \left[\mathrm{Cu}^{2+}\right]$ vs. $\log [\mathrm{Cu}]_{\mathrm{T}}$, shows seasonal variation of the complexation in the cuphotic zone (Fig. 2A), as indicated by the shift in the curves along the $x$-axis (Sunda and Huntsman 1991). The titration curve of January is shifted to the left side of April, July, and October for the samples from the euphotic zone, which means to overall less strong complexation. Only the lower part of the titration curve of January overlapped the others, indicating low concentration of strong organic ligands. Figure 2B shows a sideby-side comparison of January water between the top and bottom layers. The titration curve of the bottom-layer water has a shape similar to other winter samples, and the titration from the upper layer indicates stronger complexation at lower concentrations of $\mathrm{Cu}$.

A previous study indicated similar $\mathrm{pCu}$ values and seasonal variations of $\mathrm{pCu}$ that followed those of algal productivity in 1990 (Xue and Sigg 1993). Differences between winter and summer samplings are, however, less clear in the 1993 measurements. The stability constants of strong organic ligands, $\log K_{1 \mathrm{Cu}}=15.3 \pm 0.1$ in the euphotic zone in 1993, were an order of magnitude higher than the average calculated in 1990. This higher average may be related to the choice of sampling times in 1993, which coincided more often with algae blooms. Even the January sampling appears to have been influenced by an unusual occurrence of blue-greens during winter 1993 in comparison to other winters (H. R. Buergi pers. comm.). Lower values of $\log K_{1 \mathrm{Cu}}$ in the October samples and in the $30-\mathrm{m}$ sample in January also support the hypothesis of the production of ligands by algae.
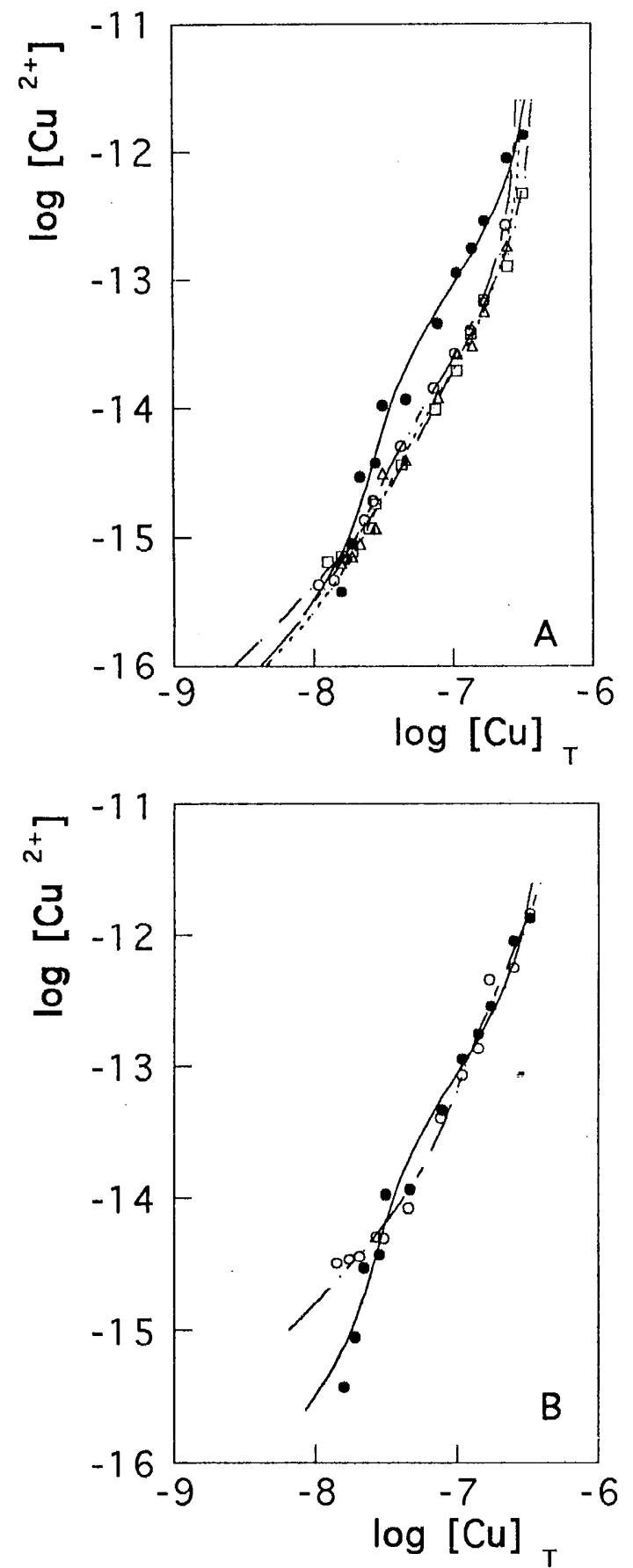

Fig. 2. Titration curves of Lake Greifen water samples with $\mathrm{Cu}$ in terms of $\log \left[\mathrm{Cu}^{2+}\right]$ as a function of $\log [\mathrm{Cu}]_{\mathrm{T}}$. The points were measured and the curves calculated with the stability constants and ligand concentrations listed in Table 1. A. Samples from the euphotic zone on different dates: (_) 26 January

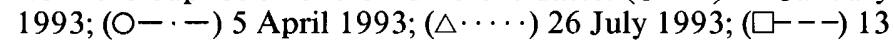
October 1993. B. Samples taken on 26 January 1993: (-) 5-m depth; (O-. - ) 30-m depth.

$\left[\mathrm{Z} \mathrm{n}^{2+}\right]$ and $\mathrm{Zn}$ speciation-The results obtained on the speciation of $\mathrm{Zn}$ indicate that, in contrast to $\mathrm{Cu}$, a substantial part of $\mathrm{Zn}$ is present as free $\mathrm{Zn}$ ions and weak organic complexes, as shown in Table 2 . Of the total 
Table 2. Zn speciations in the water column of lake Greifen. Speciation results are conditional for $\mathrm{pH}$ 8. $\left[\mathrm{ZnL}_{1}\right]$ and $\left[\mathrm{ZnL}_{2}\right]$ are the concentrations of $\mathrm{Zn}$ in the strong $\left(\mathrm{L}_{1}\right)$ and weak $\left(\mathrm{L}_{2}\right)$ complexes.

\begin{tabular}{|c|c|c|c|c|c|c|c|}
\hline \multirow[b]{2}{*}{1993} & \multirow{2}{*}{$\begin{array}{l}\text { Depth } \\
\text { (m) }\end{array}$} & \multirow{2}{*}{$\begin{array}{c}{[\mathrm{Zn}]_{\mathrm{r}}{ }^{*}} \\
(\mathrm{nM})\end{array}$} & \multirow{2}{*}{$\underset{(\mathrm{nM})}{\left[\mathrm{Zn}^{2 !}\right] \dagger}$} & \multirow[b]{2}{*}{$\mathrm{pZn}$} & \multirow{2}{*}{$\begin{array}{l}{[\mathrm{Zn}]_{\mathrm{T}}:} \\
{\left[\mathrm{Zn}^{2+}\right]}\end{array}$} & {$\left[\mathrm{ZnL}_{1}\right]^{*}$} & {$\left[\mathrm{ZnL}_{2}\right] \dagger$} \\
\hline & & & & & & \multicolumn{2}{|c|}{$(\mathrm{nM})$} \\
\hline \multirow[t]{2}{*}{$26 \mathrm{Jan}$} & 5 & 19.9 & 0.6 & 9.2 & 32.6 & 7.7 & 11.0 \\
\hline & 30 & 27.5 & 2.8 & 8.6 & 10.0 & 16.0 & 6.0 \\
\hline \multirow[t]{2}{*}{$5 \mathrm{Apr}$} & 5 & 21.4 & 0.3 & 9.5 & 64.8 & 15.7 & 5.0 \\
\hline & 30 & 29.1 & 0.4 & 9.4 & 69.3 & 20.3 & 7.9 \\
\hline \multirow[t]{4}{*}{$26 \mathrm{Jul}$} & 3 & 30.6 & 1.2 & 8.9 & 24.9 & 19.8 & 8.6 \\
\hline & 6 & 39.8 & 1.8 & 8.8 & 25.4 & 4.3 & 32.5 \\
\hline & 8 & 39.8 & 2.8 & 8.6 & 14.5 & 6.6 & 27.7 \\
\hline & 30 & 39.8 & 2.0 & 8.7 & 20.1 & 30.0 & 5.8 \\
\hline \multirow[t]{2}{*}{$13 \mathrm{Oct}$} & 2.5 & 22.9 & 0.5 & 9.3 & 43.4 & 13.8 & 8.2 \\
\hline & 11 & 36.8 & 2.3 & 8.7 & 16.3 & 12.3 & 20.4 \\
\hline \multicolumn{8}{|c|}{ Year avg in the euphotic zone } \\
\hline & & 23.7 & 0.6 & 9.2 & 37.0 & 14.2 & 8.2 \\
\hline
\end{tabular}

* Measured.

$\dagger$ Calculated from ligand exchange.

dissolved $\mathrm{Zn}, 1-10 \%$ was free $\mathrm{Zn}^{2+}$; $\mathrm{pZn}$ was thus in the range $8.5-9.5$. In the euphotic zone, $20-60 \%$ of free $\mathrm{Zn}^{2+}$ appeared to be present in weak organic complexes, while $40-80 \%$ was present in forms that were not labile to ASV determinations and were thus bound in stronger organic ligands or possibly in colloidal particles. The directly measured concentrations of $\mathrm{ZnL}_{1}$ (nonlabile complexes) indicate that strong organic ligands for $\mathrm{Zn}$ are probably only available at lower concentrations than total dissolved $\mathrm{Zn}$. The $\mathrm{L}_{1}$ concentrations given in Table 1 (obtained from modeling the $\mathrm{Cu}$ titration data) correspond to the total available strong ligands; in view of the $\mathrm{Cu}$ -

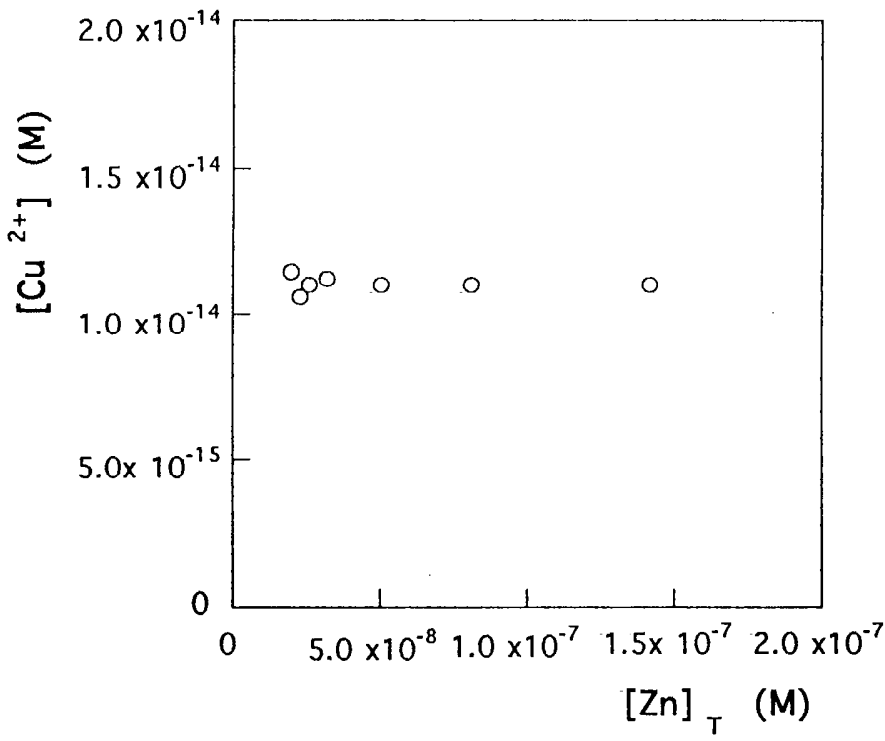

Fig. 3. Free cupric ion concentrations as a function of adding $\mathrm{Zn}$. The sample was taken at 5-m depth on 26 January 1993, and the titration was carried out in the presence of added $\mathrm{Cu}$ (31.5 nM).
$\mathrm{Zn}$ competition for them, they should be equal to the sum of $\left[\mathrm{ZnL}_{1}\right]$ and $\left[\mathrm{CuL}_{1}\right]\left(\approx[\mathrm{Cu}]_{\mathrm{T}}\right) ; \mathrm{L}_{1}$ concentrations (Table 1) are either close to this sum or in excess of it.

Competition of $\mathrm{Cu}$ and $\mathrm{Zn}$ for ligands-Addition of $\mathrm{Zn}$ seems to have no effect on $\mathrm{Cu}$ speciation (Fig. 3). There were no obvious variations of the pcak current for [Cucatechol] in titrations of original lake water with $\mathrm{Zn}$, and thus no measurable differences in $\left[\mathrm{Cu}^{2+}\right]$. As an example, free cupric ion concentrations in the presence of an additional $31.5 \mathrm{nM} \mathrm{Cu}$ are plotted in Fig. 3 as a function of added $\mathrm{Zn}$. With added $\mathrm{Zn}_{\mathrm{T}}$ in the range $1 \times 10^{-8}-2 \times 10^{-7}$ $M$, the results show no detectable effect of $\mathrm{Zn}$ additions on $\mathrm{Cu}$ speciation or on $\left[\mathrm{Cu}^{2+}\right]$ concentrations. Although the addition of $\mathrm{Cu}$ in this experiment would saturate the strong ligands, competition with $\mathrm{Zn}$ should be detectable if it were significant.

In contrast, titration of lake water with $\mathrm{Cu}$ clearly influences Zn speciation (Table 3, Fig. 4). Labile Zn concentrations increased after addition of $\mathrm{Cu}(31.5 \mathrm{nM})$; frec $\mathrm{Zn}$ ion concentrations incrcased in a similar manner (Table 3). It is likely that the added $\mathrm{Cu}$ replaced $\mathrm{Zn}$ in the strong organic complexes and that $\mathrm{Zn}$ was released to labile species. Labile $\mathrm{Zn}$ concentrations, as well as $\left[\mathrm{Zn}^{2+}\right]$, increased in all samples upon addition of $\mathrm{Cu}\left(1 \times 10^{-8_{-}}\right.$ $\left.3 \times 10^{-7} \mathrm{M}\right)$ and approached a plateau, as shown in Fig. 4. For some samples, maximal concentrations of labile $\mathrm{Zn}$ in titrations with $\mathrm{Cu}$ were close to total dissolved $\mathrm{Zn}$ (Table 4). The direct results of these experiments are the changes only in the electrochemically inert $\mathrm{Zn}$ species, which are considered to be the strong organic complexes $\left(\mathrm{ZnL}_{1}\right)$. The other changes in $\mathrm{Zn}$ speciation (relative fraction of inorganic and weak organic complexes) are obtained indirectly from the exchange with EDTA.

In the examples given in Table 3 , the increase in labile $\mathrm{Zn}$ takes place mostly as an increase of the inorganic $\mathrm{Zn}$ complexes and of $\mathrm{Zn}^{2+}$ and only of a smaller fraction as $\mathrm{ZnL}_{2}$. The results given in Table 3 represent the case of 
Table 3. Zn speciation in an original lake-water sample and after $\mathrm{Cu}$ addition. [Cu] added $-31.5 \mathrm{nM}$; samples taken on 26 January 1993; pH 8; $[\mathrm{Zn}]_{\mathrm{T}}$-dissolved $\mathrm{Zn}(<0.45 \mu \mathrm{m}) ;[\mathrm{Zn}]_{\mathrm{lab}}-$ labile $\mathrm{Zn}$ species by voltametry; $[\mathrm{Zn}]_{\text {inorg }}$-inorganic $\mathrm{Zn}$ species; $\left[\mathrm{ZnL}_{1}\right]-$ complexes of $\mathrm{Zn}$ with strong organic ligands; $\left[\mathrm{ZnL}_{2}\right]-$ complexes of $\mathrm{Zn}$ with weak organic ligands.

\begin{tabular}{|c|c|c|c|c|}
\hline & \multicolumn{2}{|c|}{ 5-m depth } & \multicolumn{2}{|c|}{ 30-m depth } \\
\hline & Orig. & $+\mathrm{Cu}$ & Orig. & $+\mathrm{Cu}$ \\
\hline$[\mathrm{Cu}]_{\mathrm{T}}(\mathrm{nM})$ & 15.7 & 47.2 & 14.2 & 45.6 \\
\hline $\mathrm{pCu}$ & 15.3 & 13.9 & 14.5 & 14.1 \\
\hline$\left[\mathrm{Cu}^{2+}\right]\left(\times 10^{-15} \mathrm{M}\right)$ & 0.5 & 11.5 & 3.2 & 8.3 \\
\hline$[\mathrm{Zn}]_{\mathrm{T}}(\mathrm{nM})$ & 19.9 & 19.9 & 27.5 & 27.5 \\
\hline$[\mathrm{Zn}]_{\text {lab }}(\mathrm{nM})$ & 12.2 & 16.4 & 11.5 & 19.6 \\
\hline$\%$ of $[\mathrm{Zn}]_{\mathrm{T}}$ & 61.3 & 82.4 & 41.8 & 71.3 \\
\hline$\left[\mathrm{ZnL}_{1}\right](\mathrm{nM})$ & 7.7 & 3.5 & 16.0 & 7.9 \\
\hline$\%$ of $[\mathrm{Zn}]_{\mathrm{T}}$ & 38.7 & 17.6 & 58.2 & 28.7 \\
\hline$\left[\mathrm{ZnL}_{2}\right](\mathrm{nM})$ & 11.0 & 11.8 & 6.0 & 8.4 \\
\hline$\%$ of $[\mathrm{Zn}]_{\mathrm{T}}$ & 55.3 & 59.3 & 21.8 & 30.6 \\
\hline$[\mathrm{Zn}]_{\text {inorg }}(\mathrm{nM})$ & 0.6 & 2.3 & 2.8 & 5.6 \\
\hline$\%$ of $[\mathrm{Zn}]_{\mathrm{T}}$ & 3.1 & 11.6 & 10.2 & 20.4 \\
\hline$\left[\mathrm{Zn}^{2+}\right](\mathrm{nM})$ & 0.6 & 2.3 & 2.8 & 5.6 \\
\hline$\%$ of $[\mathrm{Zn}]_{\mathrm{r}}$ & 3.1 & 11.6 & 10.0 & 20.4 \\
\hline
\end{tabular}

a small addition of $\mathrm{Cu}$; with higher additions of $\mathrm{Cu}$, as in the higher range of the titrations in Fig. 4, the competition of $\mathrm{Cu}$ for $\mathrm{L}_{2}$ probably also becomes more important. These results clearly indicate that competition between $\mathrm{Cu}$ and $\mathrm{Zn}$ for strong organic ligands takes place. However, it is difficult to interpret the differences from one sample to another and especially to understand in which cases the maximum labile $\mathrm{Zn}$ approaches total dissolved $\mathrm{Zn}$. These differences may be related to variations of ligand properties and possibly to the occurrence of colloidally bound $\mathrm{Zn}$.
Plots of $\left[\mathrm{ZnL}_{1}\right]\left[\mathrm{Cu}^{2+}\right] /\left[\mathrm{Zn}^{2+}\right]$ as a function of $\Delta[\mathrm{Zn}]_{\text {lab }}$ from titrations of lake-water samples with $\mathrm{Cu}$ (Fig. 5) give, in most cases, linear curves according to Eq. 12. Values of $\left[\mathrm{CuL}_{1}\right]_{0}$ obtained from these plots are usually lower than total dissolved $\mathrm{Cu}$ and thus lower than the $\mathrm{CuL}_{1}$ concentrations obtaincd from Table 1. Figure 5 shows examples in which the first few points of the titrations with $\mathrm{Cu}$ were taken into account; the simplified exchange model may no longer be valid when the exchangeable ligands are nearly saturated by $\mathrm{Cu}$ in the later parts of the titrations. In addition, for some samples, variations of the function could not be systematically obtained because of small differences between total dissolved and initially labile $\mathrm{Zn}$ concentrations which resulted in low precision. Also, many simplifying assumptions are involved in deriving Eq. 12. Exchange constants obtaincd from these plots are $\log K_{\mathrm{ex}}=5.4 \pm 0.7$ for samples from the cuphotic zone.

As mentioned above, it is difficult to distinguish between different ligands in these waters. The competition between $\mathrm{Cu}$ and $\mathrm{Zn}$ can therefore also be calculated from the speciation in the original water samples under the assumption of the same ligands for both metals (Table 4). The $\left[\mathrm{Zn}^{2+}\right]:\left[\mathrm{Cu}^{2+}\right]$ ratios were quite constant around $10^{6}$, espccially for the euphotic zone, with an average of $(1.2 \pm 0.5) \times 10^{6}$. The exchange constants, $K_{\mathrm{ex}}$, were calculated from the frce ion and strong organic complex concentrations of $\mathrm{Cu}$ and $\mathrm{Zn}$ (Eq. 13) and are in the range of $10^{6}$; the average $K_{\mathrm{ex}}$ for the euphotic zone is $(1.4 \pm 0.9)$ $\times 10^{6}$. The conditional stability constants of complexes of $\mathrm{Zn}$ with organic ligands estimated from Eq. 8 range from $10^{8}$ to $10^{9}$, with an average $\log K_{1 \mathrm{nn}}=9.0$ for the euphotic zone.

$K_{\mathrm{ex}}$ was also evaluated by Eq. 13 from the beginning part of the titrations of lake water with $\mathrm{Cu}$. In this part, $\mathrm{Cu}$ probably is mostly bound to $\mathrm{L}_{1}$, so that the assumption

Table 4. $\mathrm{Cu}-\mathrm{Zn}$ exchange parameters in water samples from Lake Greifen. $K_{\mathrm{cx}}-$ exchange constant for the reaction: $\mathrm{Cu}^{2+}+\mathrm{ZnL}_{1}=\mathrm{Zn}^{2+}+\mathrm{CuL}_{1}$, calculated from Eq. 13; $K_{1 \mathrm{Zn}}-$ conditional stability constant of the complex $\mathrm{ZnL}_{1} ;[\mathrm{Zn}]_{\mathrm{lab} \max }-$ maximum labile $\mathrm{Zn}$ concentration measured after $\mathrm{Cu}$ addition; $\mathrm{pH} 8$.

\begin{tabular}{|c|c|c|c|c|c|c|}
\hline 1993 & $\begin{array}{c}\text { Depth } \\
\text { (m) }\end{array}$ & $\begin{array}{c}{\left[\mathrm{Zn}^{2+}\right]:} \\
{\left[\mathrm{Cu}^{2+}\right]} \\
\left(\times 10^{6} \mathrm{~mol}\right. \\
\left.\mathrm{mol}^{-1}\right) \\
\end{array}$ & $\begin{array}{c}K_{\mathrm{ex}} \\
\left(\times 10^{6}\right) \\
\end{array}$ & $\begin{array}{c}K_{1 \mathrm{Zn}} \\
\left(\times 10^{8} \mathrm{M}^{-1}\right) \\
\end{array}$ & $\log K_{1 \mathrm{Zn}}$ & $\begin{array}{c}{[\mathrm{Zn}]_{\mathrm{lab} \max }} \\
(\mathrm{nM})\end{array}$ \\
\hline \multirow[t]{2}{*}{26 Jan } & 5 & 1.3 & 2.6 & 6.1 & 8.8 & 20.9 \\
\hline & 30 & 0.9 & 0.8 & 0.8 & 7.9 & 24.5 \\
\hline \multirow[t]{2}{*}{$5 \mathrm{Apr}$} & 5 & 0.8 & 0.5 & 37.0 & 9.6 & 11.8 \\
\hline & 30 & 1.1 & 0.6 & 13.0 & 9.1 & 17.1 \\
\hline \multirow[t]{4}{*}{$26 \mathrm{Jul}$} & 3 & 1.9 & 1.5 & 10.6 & 9.0 & 23.0 \\
\hline & 6 & 1.0 & 4.3 & 2.9 & 8.5 & 40.0 \\
\hline & 8 & 5.2 & 13.4 & 0.9 & 8.0 & 40.0 \\
\hline & 30 & 17.8 & 4.7 & 8.5 & 9.0 & 12.0 \\
\hline \multirow[t]{2}{*}{$13 \mathrm{Oct}$} & 2.5 & 0.8 & 0.8 & 5.8 & 8.8 & 18.4 \\
\hline & 11 & 4.2 & 4.3 & 0.7 & 7.8 & 36.8 \\
\hline \multicolumn{7}{|c|}{ Year avg in the euphotic zone } \\
\hline & & 1.2 & 1.4 & 9.0 & 9.0 & \\
\hline
\end{tabular}



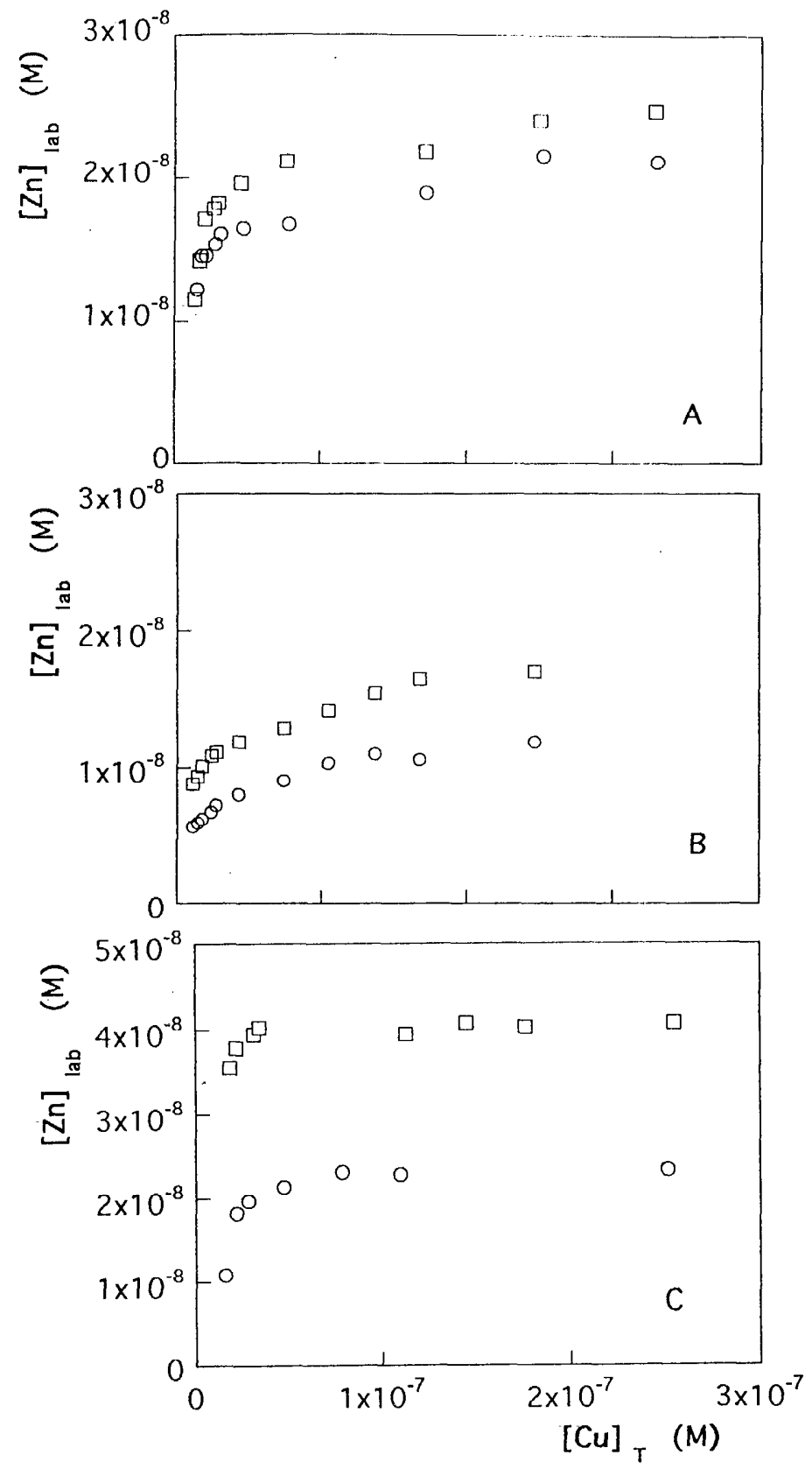

Fig. 4. Labile $\mathrm{Zn}$ as a function of adding $\mathrm{Cu}$. A. Samples taken on 26 January at 5-m depth $(O)$ and at 30-m depth ( $\square$ ). B. Samples taken on 5 April at 5-m depth $(O)$ and at 30-m depth (). C. Samples taken on 16 July at $3-\mathrm{m}$ depth $(O)$ and at $6-\mathrm{m}$ depth ( $\square)$.

$[\mathrm{Cu}]_{\mathrm{T}} \approx\left[\mathrm{CuL}_{1}\right]$ is justified. The weak organic complexing coefficients for $\mathrm{Zn}$ remain constant at the beginning of the titration, so free $\mathrm{Zn}$ ion concentrations are estimated from these coefficients and from the measured labile $\mathrm{Zn}$. The average $K_{\mathrm{ex}}$ values from the titrations were similar to those directly calculated from original samples, resulting in average $\log K_{1 \mathrm{Zn}}=8.8$.

All conditional constants obtained are at $\mathrm{pH} 8$. The errors in the exchange constants were estimated to $< \pm 0.4$

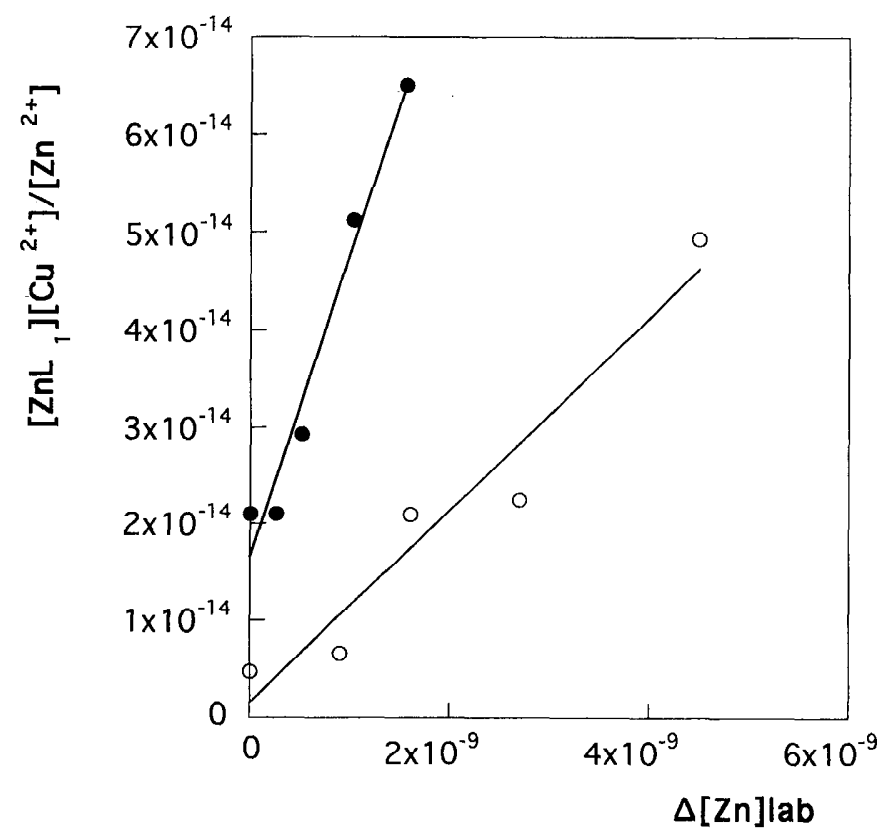

Fig. 5. Linear relationship of $\left[\mathrm{ZnL}_{1}\right]\left[\mathrm{Cu}^{2 !}\right] /\left[\mathrm{Zn}^{2+}\right]$ vs. $\Delta[\mathrm{Zn}]_{\text {lab }}$ (Eq. 12) in titrations of Lake Greifen water with Cu. Samples taken at 5-m depth on 26 January (O) and on 5 April (๑) 1993.

for $\log K_{\mathrm{ex}}$ and $\log K_{\mathrm{IZn}}$ from the precision of the $\mathrm{pCu \text {, }}$ $\left[\mathrm{Zn}^{2+}\right]$, and labile $\mathrm{Zn}$ determinations.

Figure 6 illustrates model calculations of titrations of lake water with $\mathrm{Cu}$ from the experimentally determined complexation parameters. $K_{1 \mathrm{Zn}}$ is as indicated in Table $4 ; \mathrm{L}_{1}$ is taken from the $\mathrm{Cu}$ titrations in the corresponding samples. It is assumed that competition between $\mathrm{Cu}$ and $\mathrm{Zn}$ takes place in a similar manner for $L_{2}$ as for $L_{1}$. The stability constant for the weaker $\mathrm{Zn}$ complexes was evaluated from the complexing coefficients $K_{2 z_{n}} \mathrm{~L}_{2}$ and the concentrations of $\mathrm{L}_{2}$ from the $\mathrm{Cu}$ titrations; this gives $\log$ $K_{2 \mathrm{Zn}} \approx 7$ and thus a similar sclectivity of $\mathrm{L}_{2}$ for $\mathrm{Cu}$ over $\mathrm{Zn}$ as was found for $\mathrm{L}_{1}$. Figure 6 shows that the general shape of the increase in labile $\mathrm{Zn}$ can be modeled in this way. Calculation of the different species during a titration with $\mathrm{Cu}$ shows the increase in $\mathrm{CuL}_{1}$ and the decrease in $\mathrm{ZnL}_{1}$ at the beginning of the titration. $\mathrm{ZnL}_{2}$ decreases at higher $\mathrm{Cu}$ concentrations because $\mathrm{L}_{2}$ becomes saturated with $\mathrm{Cu}$.

\section{Discussion}

All these findings, especially the rclcase of $\mathrm{Zn}$ from electrochemically inert complexes upon addition of $\mathrm{Cu}$, indicate that competition for strong organic ligands takes place between $\mathrm{Cu}$ and $\mathrm{Zn}$. A fraction of the dissolved $\mathrm{Zn}$ is originally bound to ligands, which actually have a high sclectivity for $\mathrm{Cu}$. The difference in spcciation between $\mathrm{Cu}$ and $\mathrm{Zn}$, as well as the ratios of their aquo ion concentrations, are in line with the generally much higher tendency of $\mathrm{Cu}$ for complexation with organic ligands (e.g. as derived from the Irving-Williams series, Stumm and Morgan 1981). The conditional constants obtained here 
for the exchange of $\mathrm{Cu}$ with $\mathrm{Zn}$, as well as those for the complexation of $\mathrm{Cu}$ and $\mathrm{Zn}$ by organic ligands, depend on the models used for their calculation and are averagc values over probably a number of different ligands. The concentrations of strong ligands, calculated from the titrations with $\mathrm{Cu}$, are also dependent on the model used; they indicate, however, an excess of strong ligands over the original $\mathrm{Cu}$ concentration, but in most cases not over the sum of $\mathrm{Cu}$ and $\mathrm{Zn}$. These concentrations are consistent with the observed speciation of $\mathrm{Zn}$, which includes a fraction of $\mathrm{Zn}$ bound in strong complexes and another fraction in wcak complexes and as frec ions. Small colloidal particles might play a role in the binding of both $\mathrm{Zn}$ and $\mathrm{Cu}$ in these samples; nonlabile strong ligands may bc in colloidal form. Exchange of $\mathrm{Cu}$ with $\mathrm{Zn}$, as well as exchange of $\mathrm{Cu}$ with catechol, are possible, however, indicating that $\mathrm{Zn}$ and $\mathrm{Cu}$ can be released from these compounds.

The high conditional stability constants for $\mathrm{Cu}$ and high selectivity for $\mathrm{Cu}$ over $\mathrm{Zn}$ give some information about the ligand types that might be involved. Natural ligands may be either specific ligands released by organisms (e.g. during growth or upon decay of algal material) or degradation products of biological material. In all cases, these natural ligands may include some chelating structures (e.g. amino and sulfidic functional groups). By considering which known ligands achicve a similar selectivity for $\mathrm{Cu}$, we may learn about plausible structures. Several organic chelating ligands like EDTA have stability constants for $\mathrm{Cu}$ in the range of $\log K=12-18$. An example is ethylenediiminodibutanedioic acid (EDDS), which has a stability constant with $\mathrm{Cu} \log K=18.4$ and with $\mathrm{Zn} \log K=13.5$; the conditional stability constant for $\mathrm{Cu}$ in the presence of $\mathrm{Ca}$ is calculated as $\log K=15.8$. High selectivity for $\mathrm{Cu}$ over $\mathrm{Zn}$ is mostly found in chelating ligands with several amino groups. Ethylencdiamine is an example of a simple ligand with a very high selectivity for $\mathrm{Cu}$ over $\mathrm{Zn}[\log K(\mathrm{Cu}$ en $)=10.48 ; \log K(\mathrm{Zn}$ en $)=5.66]$. Other diamine ligands and those including three and more amino groups have similar selectivities and high stability constants for $\mathrm{Cu}$ [e.g. ethylenedinitrilo-tetrakis(2-cthylamine) has $\log K 22.1$ for $\mathrm{Cu}$ and 16.1 for $\mathrm{Zn}$ ]. Some peptides, including histidine, are also highly selective for $\mathrm{Cu}$ (e.g. Gly-L-His-L-Lys, $\log K_{\mathrm{Cu}}=16.4, \log K_{\mathrm{Zn}}=8.2$ ) (all stability constants are from Martell and Smith 19741989). A structure including several amino groups, which can chelate $\mathrm{Cu}$, may occur in the natural ligands (e.g. in peptides). Very selective structures are also found in phytochelatins, the internal detoxifying ligands of algae, which may be released upon decay of algal material (Gekeler et al. 1988; Ahner et al. 1994).

It seems likely that the ligands in Lake Greifen are of biological origin. Seasonal variations and a relationship between $\mathrm{Cu}$ complexation and algal activity have been observed (Xuc and Sigg 1993). The results presented here do not show the seasonal dependence as clearly because most samplings were performed during periods with high algal activity. The presence of high concentrations of sclective ligands in the lake may be linked to the high algal productivity $\left(\sim 500 \mathrm{~g} \mathrm{C} \mathrm{m}^{-2} \mathrm{yr}^{-1}\right.$, Bührer and Wasmer
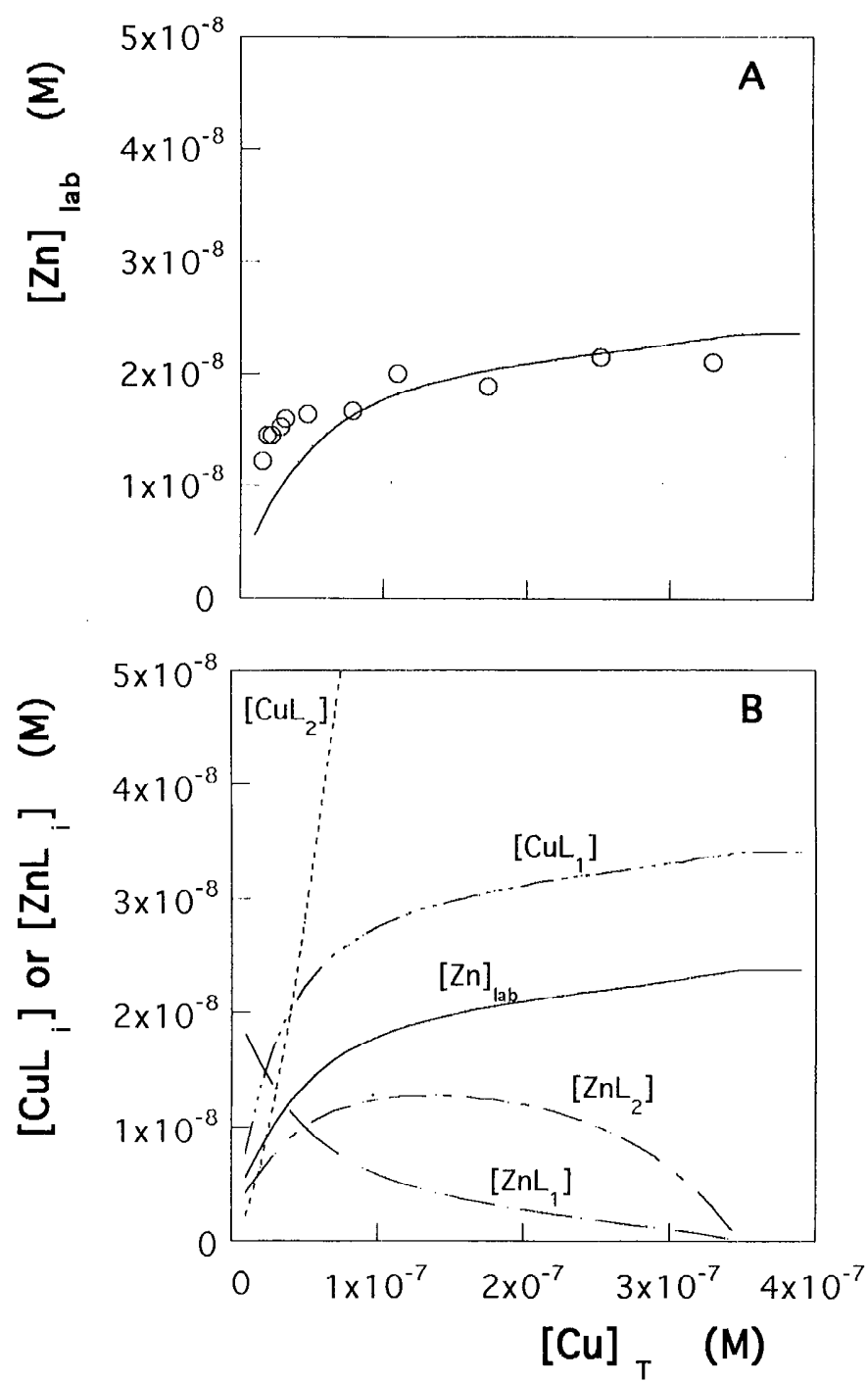

Fig. 6. Labile $\mathrm{Zn}$ concentration as a function of total dissolved $\mathrm{Cu}$ concentration (A) and calculated concentrations of $\mathrm{Cu}$ and $\mathrm{Zn}$ complexes with increasing $\mathrm{Cu}(\mathrm{B})$. In panel $\mathrm{A}$, the points were measured for the sample taken at 5-m depth on 26 January 1993 and the curve was calculated with the same two ligands for $\mathrm{Cu}$ and $\mathrm{Zn}$, using the average values in the euphotic zone for the complexation parameters: $[\mathrm{Cu}]_{\mathrm{T}}=13.8 \mathrm{nM},[\mathrm{Zn}]_{\mathrm{T}}$ $=23.7 \mathrm{nM}, C L_{1}=34 \mathrm{nM}, C L_{2}=314 \mathrm{nM}, \log K_{1 \mathrm{Cu}}=15.1$ and $\log K_{2 \mathrm{Cu}}=13.0, \log K_{1 \mathrm{Zn}}=9.2$ and $\log K_{2 \mathrm{Zn}}=7$. In panel $\mathrm{B}$, all curves were calculated as in panel A.

1992). This hypothesis is also supported by comparing Lake Greifen with less eutrophic lakes; our unpublished results on oligotrophic lakes show a lower extent of $\mathrm{Cu}$ complexation. In a similar way, only weaker complexation of $\mathrm{Cu}$ was observed in rivers downstream of sewage inputs (unpubl. results).

Because $\mathrm{Zn}$ is complexed only to a small extent and the selectivity of the ligand for $\mathrm{Cu}$ over $\mathrm{Zn}$ (e.g. $K_{\mathrm{ex}}$ ) is very high, these ligands contribute to the reduction of free cupric ion concentrations and may contribute to sustaining optimal $\mathrm{pCu}, \mathrm{pZn}$, and $\left[\mathrm{Zn}^{2+}\right]:\left[\mathrm{Cu}^{2+}\right]$ ratios. Toxicity 
of $\left[\mathrm{Cu}^{2+}\right]$ to algae has been observed at low levels $\left(10^{-12}\right.$ $10^{-10} \mathrm{M}$ ); higher concentrations of $\mathrm{Cu}$ may induce the release of strong ligands and thus an increase in complexing capacity, as has been observed for green algae in defined ionic media and in lake water (Xue and Sigg 1990; Knauer et al. in prep.). Higher levels of $\left[\mathrm{Zn}^{2+}\right]$ are tolerated by algae, so that high $\left[\mathrm{Zn}^{2+}\right]:\left[\mathrm{Cu}^{2+}\right]$ ratios may be favorable. In comparison with the toxic and limiting levels observed for marine algae (Sunda and Huntsman 1992; Brand et al. 1986; Sunda and Guillard 1976) and for some freshwater algae in culture media (Knauer et al. in prep.), both $\mathrm{pCu}$ and $\mathrm{pZn}$ in Lake Greifen would be lower than toxic levels.

More work is needed to characterize the strong and selective complexing ligands in lake water in order to understand the sources and nature of the strong ligands and their significance in sustaining low levels of $\left[\mathrm{Cu}^{2+}\right]$, optimal $\left[\mathrm{Zn}^{2+}\right]$, and $\left[\mathrm{Zn}^{2+}\right]:\left[\mathrm{Cu}^{2+}\right]$ ratios in eutrophic lakes.

\section{References}

Ahner, B. A., N. M. Price, ANd F. M. M. Morel. 1994. Phytochelatin production by marine phytoplankton at low free metal ion concentrations: Laboratory studies and field data from Massachusetts Bay. Proc. Natl. Acad. Sci. 91: 8433-8436.

BRAND, L. E., W. G. SUNDA, AND R. R. L. GuIllard. 1986. Reduction of marine phytoplankton reproduction rates by copper and cadmium. J. Exp. Mar. Biol. Ecol. 96: 225-250.

BRULAND, K. W. 1989. Oceanic zinc speciation: Complexation of zinc by natural organic ligands in the central North Pacific. Limnol. Oceanogr. 34: 267-283.

$\longrightarrow$ J. R. Donat, AND D. A. Hutchins. 1991. Interactive influences of bioactive trace metal on biological production in oceanic water. Limnol. Oceanogr. 36: 1555-1577.

BÜHRER, H., AND H. WASMER. 1992. Gutachten über die Möglichkeit einer Sanierung des Greifensees. Amt für Gewässerschutz des Kantons Zürich. Auftrag No. 4815. EAWAG.

Coale, K. H., AND K. W. Bruland. 1990. Spatial and temporal variability in copper complexation in the North Pacific. Deep-Sea Res. 37: 317-336.

DONAT, J. R., AND K. W. BRULAND. 1990. A comparison of two voltammetric techniques for determining zinc speciation in northeast Pacific Ocean waters. Mar. Chem. 28: 301323.

Gekeler, W., E. Grill, E.-L. Winnacker, ANd M. H. Zenk. 1988. Algae sequester heavy metals via synthesis of phytochelatin complexes. Arch. Microbiol. 150: 197-202.

Martell, A. E., AND R. M. SMith. 1974-1989. Critical stability constants. V. 1-6. Plenum.
Meyns, S., R. Illi, AND B. RiBi. 1994. Comparison of chlorophyll $a$ analysis by HPLC and spectrophotometry: Where do the differences come from? Arch. Hydrobiol. 132: 129139.

MülLER, B. 1993. Mac $\mu \mathrm{QL}$, a program to calculate chemical speciation and adsorption. EAWAG.

Sigg, L., A. KunN, H. Xue, E. Kiefer, ANd D. Kistler. 1995. Cycles of trace elements (copper and zinc) in a eutrophic lake: Role of speciation and sedimentation, p. 177-194. In Aquatic chemistry: Interfacial and interspecies processes. Adv. Chem. Ser. 244.

Stumm, W., AND J. J. Morgan. 1981. Aquatic chemistry, 2nd ed. Wiley-Interscience.

SundA, W. G. 1994. Trace metal/phytoplankton interactions in the sea, p. 213-247. In G. Bidoglio and W. Stumm [eds.], Chemistry of aquatic systems: Local and global perspectives. Kluwer.

—_ AND R. R. L. GuillaRd. 1976. The relationship between cupric ion activity and the toxicity of copper to phytoplankton. J. Mar. Res. 34: 511-529.

- AND S. A. Huntsman. 1991. The use of chemiluminescence and ligand competition with EDTA to measure copper concentration and speciation in seawater. Mar. Chem. 36: 137-163.

- AND - -1992 . Mutual feedback interactions between zinc and phytoplankton in seawater. Limnol. Oceanogr. 37: 25-40.

VAN DEN BERG, C. M. G. 1984. Determination of the complexing capacity and conditional stability constants of complexes of copper(II) with natural organic ligands in seawater by cathodic stripping voltammetry of copper-catechol complex ions. Mar. Chem. 15: 1-18.

Westall, J. C. 1979. MICROQL-1. A chemical equilibrium program in basic. EAWAG,

1982. FITEQL. A program for the determination of chemical equilibrium constants from experimental data. Oregon State Univ.

WhITFIELD, M., AND D. R. TURNER. 1987. The role of particles in regulating the composition of seawater, p. 457-493. In W. Stumm [ed.], Aquatic surface chemistry. Wiley-Interscience.

Xue, H. B., AND L. SigG. 1990. Binding of $\mathrm{Cu}(\mathrm{II})$ to algae in a metal buffer. Water Res. 24: 1129-1136. , AND - 1993. Free cupric ion concentration and $\mathrm{Cu}(\mathrm{II})$ speciation in a eutrophic lake. Limnol. Oceanogr. 38: 1200-1213.

, AND - 1994. Zinc speciation in lake waters and its determination by ligand exchange with EDTA and differential pulse anodic stripping voltammetry. Anal. Chim. Acta 284: 505-513.

Submitted: 8 August 1994 Accepted: 13 February 1995 Amended: 24 April 1995 